\title{
Poor prognosis of acute lymphoblastic leukaemia in Asian children living in the United Kingdom
}

\author{
A OAKHILL, JILLIAN R MANN
}

\begin{abstract}
A study of the results of treatment of acute lymphoblastic leukaemia in Asian (Indian and Pakistani) children living in the United Kingdom showed that they had a poorer prognosis than native white children due mainly to deaths during remission. Similar proportions of Asian and white children suffered relapse.

Lower socioeconomic status, poor nutrition, and difficulties in communication may have contributed to the worse outcome in the Asian children.
\end{abstract}

\section{Introduction}

Several reports from the United States ${ }^{1-4}$ have indicated that black children with acute lymphoblastic leukaemia fared worse than white children. These studies assessed durations of remission and survival in children treated from 1955 to 1969 , when the results of treatment were poor compared with those achieved now. They showed, however, that being Negro and of a low socioeconomic status were poor prognostic features. We compared the results of treatment of acute lymphoblastic leukaemia in Asian and in native white children.

\section{Patients and methods}

Thirty Indian and Pakistani children (18 boys, 12 girls) living in the United Kingdom were treated in the Medical Research Council's United Kingdom acute lymphoblastic leukaemia (UKALL) trials between January 1972 and July 1978. Their clinical state was assessed on 1 July 1981. Three were treated in the UKALL II trial, 10 in UKALL III (four "intensive," six "ordinary"), four in UKALL IV, 12 in UKALL V (seven "intermittent," five "continuous"), and one in UKALL VI.

A control group of white patients matched for age $(+2.4$ years, usually $t 1$ year), sex, white cell count $<$ or $\geqslant 20 \times 10^{9} / 1$ at presentation), and UKALL trial was selected by taking the two patients in whom leukaemia had been diagnosed nearest to the date of diagnosis in each Asian patient.

Life tables of the duration of first remission in the two groups were obtained and the logrank test used to calculate the significance of differences between the groups. ${ }^{5}$ Median durations of remission were derived from the curves. The nutrition of children in the two groups was studied by comparing their heights and weights at diagnosis using the British standard growth charts. ${ }^{6}$ The results were expressed as standard scores defined as the number of standard deviations (SD) by which the measurements differed from the mean for healthy white populations of the same age and sex. ${ }^{7}$

\section{Results}

The ages of the Asian patients ranged from 0.6 to 13.3 years; the peak of incidence of leukaemia was at ages 3-4 years. Their haemoglobin concentrations ranged from 1.6 to $11.9 \mathrm{~g} / \mathrm{dl}$, white cell counts

Children's Hospital, Birmingham B16 8ET

A OAKHILL, MRCP, Leukaemia Research Fund oncology training fellow JILLIAN R MANN, FRCP, consultant paediatric oncologist

Correspondence to: Dr J R Mann. from $1 \cdot 1$ to $680 \times 10^{9} / 1$, and platelet counts from 1 to $215 \times 10^{9} / 1$. "Common" acute lymphoblastic leukaemia was diagnosed in all three children whose cells were tested for membrane markers. ${ }^{8}$

Table I compares the presenting features of the Asian and white children. Slightly larger proportions of the white children had adverse prognostic features-that is, age less than 2 or 14 years and over, white cell count $\geqslant 50 \times 10^{9} / 1$, or the presence of a mediastinal mass. Mean SD scores for both height and weight were lower in the Asian children than the white children (fig 1), but there was considerable individual variation. Because of the need to match the Asian and control children for age, sex, white cell count, and UKALL trial it was not possible also to match them precisely by treatment centre. Nevertheless, similar proportions came from large industrial conurbations ( 24 of the 30 Asians and 43 of the 60 controls).

Compliance with treatment was assessed by studying the haematological charts of 12 Asian and control children who were treated at one centre. As judged by the frequency of episodes of neutropenia, there seemed to have been little difference between the two groups.

The median duration of remission (fig 2) was shorter in the Asian than the white children (23 $v 45$ months), and smaller proportions of Asian than white children were still in continuous complete remission after two and five years $\left(\chi^{2}=12.66, p<0.001\right.$ and $\chi^{2}=3.28, p<0.1$ respectively; table II). These differences were largely accounted for

TABLE I-Clinical and haematological features in patients (all figures are numbers of patients)

\begin{tabular}{|c|c|c|c|c|c|c|c|c|}
\hline & & & & & & & $\begin{array}{l}\text { Asian } \\
\text { children }\end{array}$ & $\begin{array}{l}\text { White } \\
\text { children }\end{array}$ \\
\hline \multicolumn{9}{|l|}{ Sex: } \\
\hline Male & . & . & . & .. & . & . & 18 & 36 \\
\hline $\begin{array}{c}\text { Female } \\
\text { Age (years). }\end{array}$ & * & . & $\cdots$ & . & $\cdots$ & . & 12 & 24 \\
\hline Age (years): & & & .. & & & & 4 & \\
\hline $2-<10$ & .. & $\therefore$ & $\therefore$ & . & .. & . & 22 & 47 \\
\hline $10-<14$ & . & .. & . & . & . & . & 4 & 6 \\
\hline$\geqslant 14$ & & $\because$ (n) & . & .. & . & . & 0 & 1 \\
\hline \multicolumn{9}{|c|}{ Mean SD score (and SD): } \\
\hline Height & . & . & . & .. & . & . & $-0.26(1.13)$ & $+0.2(0.95)$ \\
\hline \multirow{2}{*}{\multicolumn{9}{|c|}{ White cell count $\left(\times 10^{9} / 1\right)$ : }} \\
\hline & & & & $\ldots$ & $\cdots$ & $\cdots$ & 15 & 26 \\
\hline $10-<50$ & . & . & $\cdots$ & . & . & .. & 11 & 24 \\
\hline$\geqslant 50$ & & . & . & . & . & . & 4 & 10 \\
\hline Mediastinal & mass & . & . & . & . & $\ldots$ & 0 & 2 \\
\hline \multicolumn{9}{|c|}{ Relapses: } \\
\hline Haematol & gical & . & $\cdots$ & .. & . & . & 12 & 26 \\
\hline Testicular & & & & . & . & .. & 2 & 5 \\
\hline Haematol & gical & ad testic & cular & . & . & . & 0 & 1 \\
\hline Central ne & rvous & ystem & & . & & . & 3 & 3 \\
\hline \multirow{2}{*}{\multicolumn{6}{|c|}{$\begin{array}{l}\text { Central nervous system and haematological } \\
\text { Died in complete continuous remission }\end{array}$}} & .. & 0 & 1 \\
\hline & & & & & & . & 4 & 1 \\
\hline \multicolumn{6}{|c|}{ Alive in complete continuous remission $\ldots$} & . & 9 & 23 \\
\hline
\end{tabular}

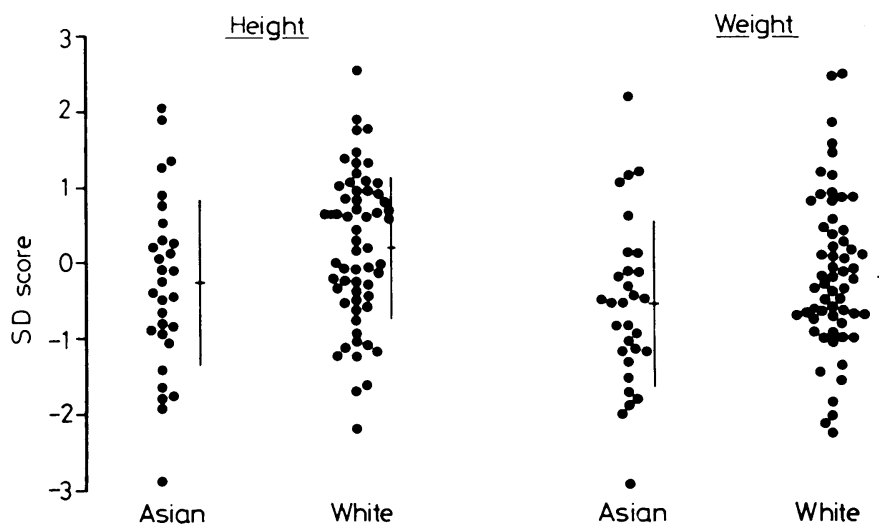

FIG 1 -SD scores for height $(p<0.05)$ and weight $(p<0.2$; Student's $t$ test) of Asian and white patients; mean and SD for each group also shown. 
TABLE II-Complete continuous remission (CCR) in Asian and white children

\begin{tabular}{|c|c|c|c|}
\hline & $\begin{array}{c}\text { Proportion in CCR } \\
\text { at } 2 \text { years }\end{array}$ & $\begin{array}{c}\text { Proportion in CCR } \\
\text { at } 5 \text { years }\end{array}$ & $\begin{array}{l}\text { Median duration } \\
\text { of remission } \\
\quad \text { (months) }\end{array}$ \\
\hline $\begin{array}{l}\text { Asian } \\
\text { White }\end{array}$ & $\left.\begin{array}{l}0.41 \\
0.80\end{array}\right\} p<0.001$ & $\left.\begin{array}{l}0.27 \\
0.39\end{array}\right\} \mathrm{p}<0.01$ & $\begin{array}{l}23 \\
45\end{array}$ \\
\hline
\end{tabular}

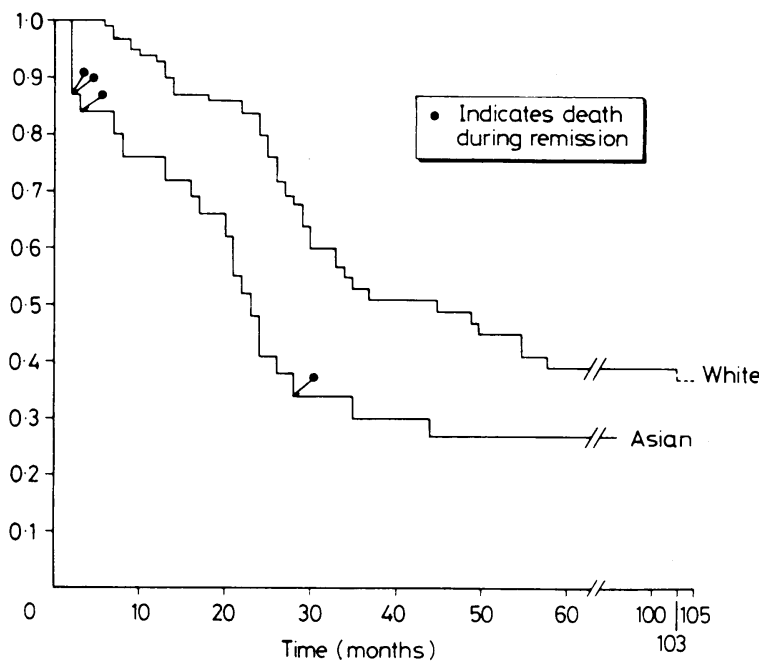

FIG 2-Duration of first remission in Asian and white children

by the fact that more Asians died in remission (table I, fig 3), although after censoring for deaths in remission there was still a small difference after two years $\left(\chi^{2}=8.58, p>0.005\right)$, which disappeared at five years. Similar proportions of the two groups ultimately developed haematological, testicular, or meningeal relapse, although there was a tendency for the Asians to relapse earlier. Table III gives details of the four Asian children and one white child who died in remission. The fact that the SD scores for weight at diagnosis were substantially below those for height in two of the Asians and the only white child who died may have some importance.

\section{Discussion}

In an American series six factors at presentation were shown to have special prognostic importance in children with acute lymphoblastic leukaemia-namely, initial white cell count, platelet count, haemoglobin concentration, sex, age, and lymphadenopathy. ${ }^{9}$ Also important were central nervous system disease at diagnosis, mediastinal mass, morphology of the lymphoblasts, cell surface markers, serum immunoglobulin concentrations, response to induction treatment, and race. ${ }^{9}$ An analysis of the patients in the Medical Research Council's UKALL II to V trials (J Peto, unpublished data) also showed that the white cell count, age, sex, platelet count, lymphadenow pathy, and mediastinal mass were important factors.

The effect of ethnic group on prognosis has been difficult $t \&$ assess as most series have consisted of unmatched patientstreated during the early 1960s, when treatment was inadequate? by present standards. Walters $e t a l^{2}$ found that Negro childre $\overline{\overline{\bar{T}}}$ treated between 1962 and 1969 had a poorer prognosis thang white children treated at the same time. They related this finding to a different natural history of the leukaemia (for example black children did not show the peak age incidence between and 5 years present in white children), more advanced diseas $\overrightarrow{\vec{E}}$ at presentation, and poverty. Pendergrass $e t a l^{3}$ confirmed these findings and stated that the difference was due to socioeconomig factors.

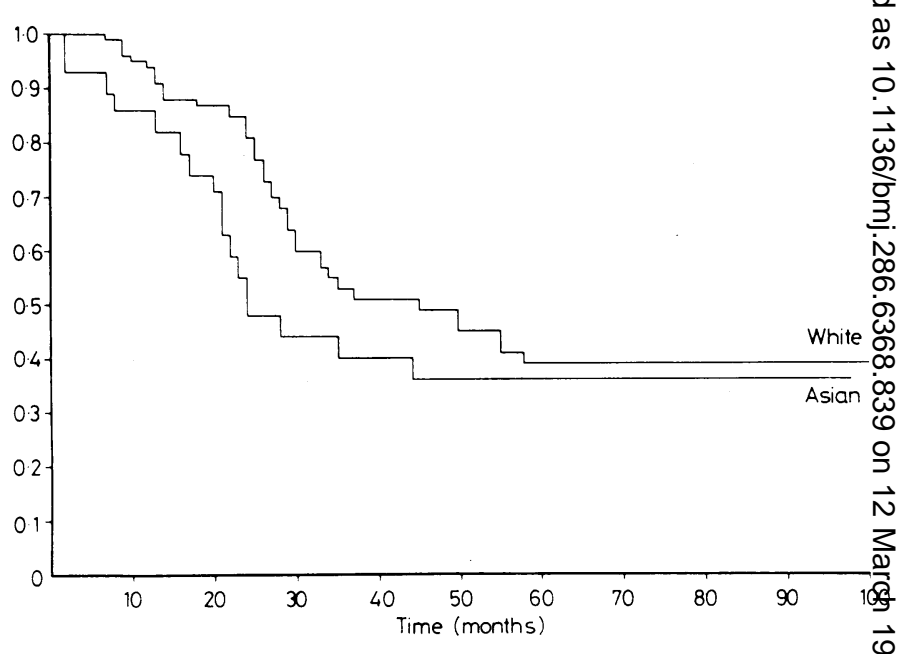

FIG 3-Duration of first remission in Asian and white children censorege for deaths during remission.

Asian children with acute lymphoblastic leukaemia treated i⿸户㔾 the Medical Research Council's trials appeared clinically to bs similar to indigenous children, with a preponderance of boys, peak age incidence at 3-4 years (unlike in American Negre patients ${ }^{1011}$, and similar haematological findings. They appearech however, to have a smaller chance of being cured of leukaemia than white children, mainly because of deaths in remission Socioeconomic factors and nutrition may possibly have been responsible for their poorer outlook. Infant mortality an morbidity are higher in Asians than whites ${ }^{12}$ in the United Kingdom, and low birth weight is common and probably relate to poor maternal nutrition. Asian children are also at risk of dietary deficiencies as shown by the high incidences of rickets ${ }^{13}$ 界 and iron deficiency. ${ }^{15}$ Poor nutrition has an adverse effect on tolerance and response to chemotherapy, ${ }^{16}$ so the lower mean height and weight scores in our Asian patients may have beef important. The standards used were derived from a healthy

TABLE III-Details of patients who died in remission

\begin{tabular}{|c|c|c|c|c|c|c|c|c|c|}
\hline \multirow{2}{*}{ Group } & \multirow{2}{*}{ Sex } & \multirow{2}{*}{$\begin{array}{c}\text { Age } \\
\text { when } \\
\text { died } \\
\text { (years) }\end{array}$} & \multicolumn{2}{|c|}{ SD scores at diagnosis } & \multirow{2}{*}{$\begin{array}{l}\text { Presenting } \\
\text { white cell } \\
\text { count } \\
\left(\times 10^{\circ} / 1\right)\end{array}$} & \multirow{2}{*}{ Treatment schedule } & \multirow{2}{*}{ Cause of death } & \multirow{2}{*}{ Survival } & \multirow{2}{*}{$\begin{array}{c}\text { ₹ } \\
\stackrel{C}{\mathbb{D}} \\
\stackrel{D}{+}\end{array}$} \\
\hline & & & Height & Weight & & & & & \\
\hline Asian & - $\mathrm{M}$ & $2 \cdot 2$ & $+1 \cdot 24$ & $+2 \cdot 21$ & 16.9 & UKALL III ordinary: 2400 rads in & Bacterial pneumonia (Streptococcus & 12 weeks & to \\
\hline Asian & $M$ & $2 \cdot 8$ & $+1 \cdot 35$ & -0.55 & $41 \cdot 5$ & $\begin{array}{l}\text { UKALL III intensive: } 500 \text { rads in } \\
\text { two fractions (died during } \\
\text { radiotherapy) }\end{array}$ & $\begin{array}{l}\text { Pneumonia with lung abscesses } \\
\text { (organism not identified) }\end{array}$ & 6 weeks & 官 \\
\hline Asian & F & $4 \cdot 9$ & -0.65 & $-1 \cdot 21$ & $45 \cdot 0$ & $\begin{array}{l}\text { UKALL IV: died before } \\
\text { radiotherapy given }\end{array}$ & $\begin{array}{l}\text { Pyogenic meningitis, previous } \\
\text { septicaemia (organism not } \\
\text { identified) }\end{array}$ & 7 weeks & बृ \\
\hline Asian & $M$ & $5 \cdot 3$ & -0.9 & -0.49 & $13 \cdot 8$ & UKALL V continuous : 2100 rads & Chickenpox & 26 months & \\
\hline White & $M$ & $1 \cdot 7$ & -0.97 & $-2 \cdot 15$ & $199 \cdot 0$ & $\begin{array}{l}\text { UKALL III intensive : } 2500 \text { rads in } \\
10 \text { fractions }\end{array}$ & $\begin{array}{l}\text { Pneumonia (organism not } \\
\text { identified). Five months } \\
\text { previously had developed fits, } \\
\text { hemiparesis, and blindness after } \\
\text { measles contact }\end{array}$ & 9 months & ํㅡㄹ. \\
\hline
\end{tabular}


British white population, but there is evidence that such standards are applicable for measuring child growth in other cultures, ${ }^{17}$ although this is controversial. ${ }^{18}$ As ours was a retrospective study data were not available on the children's iron and calcium metabolism; and we did not have details about the economic circumstances of the Asian and control families and their social class distribution.

Language problems may also have contributed to the poorer result in the Asian children, since the treatment and its complications were difficult to explain to people whose first language was not English and who were not accustomed to Western medicines. This factor may also have contributed to the higher incidence of deaths in remission among the Asian children as their parents may have been insufficiently aware of early signs and symptoms of infection and of other complications of chemotherapy. Poor communication might also have led to poor compliance, although there was no increased rate of leukaemic relapse in the Asians compared with the white controls.

Improvement in the results of treating Asian children with acute lymphoblastic leukaemia might be achieved by better attention to nutrition and by further attempts to overcome communication difficulties. More studies are required to determine whether other factors may influence the outcome in Asian children.

We thank Dr H E M Kay, Miss M Gilham, Miss A M Fenwick, and Dr A Rankin for help; Dr J Peto for permission to quote his analysis of the prognostic features in the UKALL II to V trials; the Leukaemia Research Fund for financial support; and Mrs K Evans and Mrs $\mathbf{N}$ Hartley for typing the manuscript.

\section{References}

1 George SL, Fernbach DJ, Vietti TJ, et al. Factors influencing survival in pediatric acute leukemia. The SWCCSG experience 1958-1970. Cancer $1973 ; 32: 1542-53$.
2 Walters TR, Bushore M, Simone J. Poor prognosis in Negro children with acute lymphoblastic leukaemia. Cancer 1972;29:210-4.

3 Pendergrass TW, Hoover R, Godwin JD. Prognosis of black children with acute lymphoblastic leukaemia. Med Pediatr Oncol 1975;1:143-8.

4 Szklo M, Gordis L, Tonascia J, Kaplan E. The changing survivorship of white and black children with leukaemia. Cancer 1978;42:59-66.

5 Peto R, Pike MC, Armitage P, et al. Design and analysis of randomised clinical trials requiring prolonged observation of each patient. II. Analysis and examples. Br $\mathcal{F}$ Cancer 1977;35:1-39.

6 Tanner JM, Whitehouse RH, Takaishi $M$. Standards from birth to maturity for height, weight, height velocity and weight velocity: British children, 1965. Part I. Arch Dis Child 1966;41:454-71.

${ }^{7}$ Tanner JM, Whitehouse RH, Takaishi $M$. Standards from birth to maturity for height, weight, height velocity and weight velocity: British children, 1965. Part II. Arch Dis Child 1966;41:613-35.

${ }^{8}$ Chessells JM, Hardisty RM, Rapson NT, Greaves MF. Acute lymphoblastic leukaemia in children. Classification and prognosis. Lancet 1977; ii:1307-9.

${ }^{9}$ Robison L, Sather H, Coccia PF, et al. Assessment of the inter-relationship of prognostic factors in childhood acute lymphoblastic leukaemia. $A m \mathcal{F}$ Pediatr Hematol Oncol 1980;2:5-12.

10 Gordis L, Moyses S, Thompson B, Kaplan A, Tonascia JA. An apparent increase in the incidence of acute non-lymphocytic leukaemia in black children. Cancer $1981 ; 47: 2763-8$.

11 Anonymous. Leukaemia in black and white. (Editorial.) Lancet 1981 ;ii: 732-3.

12 Adelstein AM, Davies IM, Weatherall JA. Perinatal and infant mortality: social and biological factors 1975-77. London: HMSO, 1980. (Studies in Medical and Population Subjects No 41.)

13 Preece MA, Ford JA, McIntosh WB, Dunnigan MG, Tomlinson S, O'Riordan JLH. Vitamin D deficiency among Asian immigrants to Britain. Lancet 1973;i:907-10.

14 Cooke WT, Swan CHJ, Asquith P, Melikian V, McFeely WE. Serum alkaline phosphatase and rickets in urban schoolchildren. $\mathrm{Br} \mathrm{Med} \mathcal{F}$ $1973 ; \mathrm{i}: 324-7$.

15 Stuart J, Schwartz FCM, Little AJ, Raine DN. Screening for abnormal haemoglobins: a pilot study. $B r$ Med f 1973;iv:284-7.

${ }^{16}$ van Eys J. Nutritional therapy in children with cancer. Cancer Res 1977; 37:2457-61.

17 Graiter PL, Gentry EM. Measuring children: one reference for all. Lancet 1981 ;ii :297-9.

18 Euebio JS, Nubé M. Attainable growth. Lancet 1981 ;ii:1223.

(Accepted 19 fanuary 1983)

\title{
Incidence of self poisoning in patients prescribed psychotropic drugs
}

\author{
KEREN SKEGG，D C G SKEGG，S M RICHARDS
}

\begin{abstract}
The drugs most commonly used in self poisoning are the psychotropics, but the proportion of patients given these drugs who take overdoses is unknown. In a prospective study of 43117 people in Oxfordshire, prescriptions issued by general practitioners were linked with records of hospital admissions and deaths. During two years there were 79 episodes of deliberate self poisoning leading to hospital admission or death. The number of patients who took overdoses of psychotropic drugs was small in relation to the total number pre-
\end{abstract}

University of Otago Medical School, Dunedin, New Zealand KEREN SKEGG, MB, MRCPSYCH, senior lecturer in psychological medicine D C G SKEGG, MB, DPHIL, professor of preventive and social medicine

Radcliffe Infirmary, Oxford OX2 6HE

S M RICHARDS, BA, DPHIL, research assistant

Correspondence and requests for reprints to: Dr Keren Skegg. scribed such drugs. Of 5600 people aged 10 or older who received psychotropic drugs during one year, 17 (3.0 per 1000) poisoned themselves with these drugs within 12 months. The rate of self poisoning with psychotropic drugs declined significantly with increasing age $(p<$ 0.001).

Almost three quarters of the patients who took overdoses of prescribed psychotropics received further psychotropic drugs during the three months after their admission to hospital.

\section{Introduction}

Whenever a medicine is prescribed there is a risk that the patient may deliberately take an overdose. Despite extensive research on self poisoning, ${ }^{12}$ the proportion of patients given drugs who poison themselves is not known. Such information is especially important for evaluating the clinical use of psychotropic drugs. ${ }^{34} \mathrm{We}$ were able to examine this question during a prospective study of medicines prescribed in general practice. 